\title{
DETERMINASI HARGA SAHAM MELALUI ANALISIS TERHADAP FAKTOR INTERNAL DAN EKSTERNAL PERUSAHAAN
}

\author{
I Wayan Wardita ${ }^{1 *}$, I B Swaputra ${ }^{2}$, I Made Purba Astakoni ${ }^{3}$ dan Ni Putu Nursiani ${ }^{4}$ \\ ${ }^{1,2,3}$ Dosen Tetap Pada Prodi Manajemen Sekolah Tinggi Ilmu Manajemen Handayani Denpasar \\ ${ }^{4}$ Dosen Tetap Pada Prodi Manajemen Fak Ekonomi \& Bisnis Univ Nusa Cendana (Undana) Kupang-NTT \\ *e-mail: sokhitel19997@gmail.com
}

DiPublikasi: 01/01/2021

http://dx.doi.org/10.22225/kr.11.2.1154.190-196

\begin{abstract}
This research has several objectives namely; 1) to find out and analyze the effect of profitability on stock prices; 2) to find out and analyze the effect of earnings per share on stock prices; 3) to find out and analyze the effect of leverage on stock prices, 4) to find out and analyze the influence of interest rates on stock prices, 5) to find out and analyze the effect of inflation on stock prices; 6) to find out and analyze the effect of exchange rates on stock prices. The population in this study are cosmetics and household use manufacturing companies listed on the Indonesia Stock Exchange (BEI) for the period 2011-2018. Sampling was done purposively with predetermined criteria. The data analysis of this study uses the Partial Least Square (PLS) approach. The result of calculating the accuracy of the model by looking at the coefficient of determination explains the structural relationship of the seven variables studied is equal to 0.577 (or 57.70\%), or in other words, the information contained in the data $57.70 \%$ can be explained by the model. The test results show that first hypothesis; which states that there is a significant positive effect between profitability on stock prices can be accepted. Second hypothesis; which states that there is a significant positive effect between earnings per share on stock prices can be accepted. Third hypothesis; which states that there is a significant negative effect between leverage on stock prices can not be accepted. Fourth hypothesis; which states that there is a significant negative effect between inflation on stock prices is not acceptable. The fifth hypothesis; which states that there is a significant negative effect between interest rates on stock prices is not acceptable. The sixth hypothesis; which states that there is a significant negative effect between the exchange rate / exchange rate on the stock price is not acceptable.
\end{abstract}

Keywords: Profitability, Earnings per Share, Leverage, Inflation, Interest Rates, Exchange Rates, Stock Prices, Panel Data.

\begin{abstract}
Abstrak
Penelitian ini memiliki beberapa tujuan yaitu; 1) untuk mengetahui dan menganalisis pengaruh profitabilitas terhadap harga saham ; 2) untuk mengetahui dan menganalisis pengaruh laba perlembar saham terhadap harga saham ; 3) untuk mengetahui dan menganalisis pengaruh leverage terhadap harga saham ;4) untuk mengetahui dan menganalisis pengaruh suku bunga terhadap harga saham;5) untuk mengetahui dan menganalisis pengaruh inflasi terhadap harga saham; 6) untuk mengetahui dan menganalisis pengaruh nilai tukar terhadap harga saham. Populasi dalam studi ini adalah perusahaan manufaktur sektor kosmetik dan keperluan rumah tangga yang terdaftar di Bursa Efek Indonesia (BEI) periode 2011-2018. Pengambilan sampel dilakukan secara purposive dengan kriteria yang telah ditetapkan sebelumnya. Analisis data studi ini menggunakan pendekatan Partial Least Square (PLS). Hasil perhitungan ketepatan model dengan melihat koefisien determinasi menjelaskan hubungan struktural dari ketujuh variabel yang diteliti adalah sebesar 0,577 (atau 57,70\%), atau dengan kata lain, informasi yang terkandung dalam data 57,70\% dapat dijelaskan oleh model tersebut.Hasil pengujian menunjukkan bahwa hipotesis pertama; yang menyatakan bahwa terdapat pengaruh signifikan positif antara profitabilitas terhadap harga saham dapat diterima. Hipotesis kedua; yang menyatakan bahwa terdapat pengaruh signifikan positif antara laba per lembar saham terhadap harga saham dapat diterima. Hipotesis ketiga; yang menyatakan bahwa terdapat pengaruh signifikan negative antara leverage terhadap harga saham tidak dapat diterima. Hipotesis keempat; yang menyatakan bahwa terdapat pengaruh signifikan negative antara inflasi terhadap harga saham tidak dapat diterima. Hipotesis kelima; yang menyatakan bahwa terdapat pengaruh signifikan negative antara tingkat suku bunga terhadap harga saham tidak dapat diterima. Hipotesis keenam; yang menyatakan bahwa terdapat pengaruh signifikan negative antara nilai tukar/kurs terhadap harga saham tidak dapat diterima.
\end{abstract}

Kata Kunci : Profitabilitas, Laba per Lembar Saham, Leverage, Inflasi,Suku Bunga, Nilai Tukar, Harga Saham, Data Panel.

\section{PENDAHULUAN}

Pada zaman modern ini, suatu perusahaan diwajibkan untuk melakukan inovasi, ekspansi, dan selalu berusaha untuk meningkatkan kinerjanya agar dapat bersaing dengan kompetitorkompetitornya. Dalam melakukan inovasi dan ekspansi, suatu perusahaan memerlukan tambahan modal yang jumlahnya tidak sedikit. Salah satu 
sarana untuk mendapatkan tambahan modal tersebut melalui pasar modal yang ada di Indonesia yaitu Bursa Efek Indonesia (BEI). Secara umum perusahaan menerbitkan saham yang dapat dimiliki oleh setiap investor guna memperoleh tambahan modalnya. Harga saham suatu perusahaan ditentukan oleh demand dan supply antara penjual dan pembeli. Biasanya demand dan supply ini dipengaruhi baik oleh faktor internal maupun eksternal perusahaan. Faktor internal merupakan faktor yang berhubungan dengan tingkat kinerja perusahaan yang dapat dikendalikan oleh manajemen perusahaan. Faktor internal tersebut seperti kebijakan dividen, likuiditas perusahaan, profitabilitas, rasio utang dan equity, serta rasio keuangan lainnya. Sedangkan faktor eksternal merupakan hal-hal di luar kemampuan manajemen perusahaan untuk mengendalikannya, seperti adanya isu politik, perubahan kurs, laju inflasi yang tinggi, tingkat suku bunga deposito, dan lain-lain (Sha 2015).

Bagi investor yang menanamkan dananya dalam bentuk saham perlu mempertimbangkan informasi yang relevan dengan kondisi pasar modal sehingga dapat terhindar dari kesalahan pengambilan keputusan untuk berinvestasi. Salah satu informasi yang diperlukan oleh investor adalah laporan keuangan perusahaan, dimana laporan keuangan biasanya dapat mencerminkan kondisi keuangan perusahaan. Oleh karena itu, investor harus memilih perusahaan yang mempunyai reputasi yang baik. Husnan dan Pudjiastuti (2010, 264) menjelaskan dengan semakin berkembangnya pasar modal khususnya di Indonesia, mengakibatkan semua informasi yang bersifat relevan dapat digunakan sebagai masukan atau dasar pertimbangan di dalam menilai suatu harga saham. Terkait dengan uraian diatas maka penelitian ini dilakukan untuk meneliti pengaruh factor internal maupun eksternal perusahaan yang memiliki dampak terhadap perubahan harga saham.Menurut Tandelilin $(2001,247)$ "salah satu indikator internal penting untuk menilai prospek perusahaan di masa datang adalah dengan melihat sejauh mana pertumbuhan profitabilitas perusahaan" Selain profitabilitas faktor internal dalam penelitian ini menggunakan laporan keuangan berupa laba per lembar saham dan leverage. Faktor eksternal yang akan diteliti menggunakan pengumuman dari pemerintah yaitu inflasi,suku bunga (BI rate) dan nilai tukar. Ketiga indikator tersebut dapat menggambarkan situasi perekonomian negara karena berhubungan dengan pasar modal.

Secara kajian teoritis faktor internal yakni profitabilitas ,laba per lembar saham (EPS) dan leverage yang memiliki pengaruh positif terhadap harga saham tidak tercermin dari beberapa hasil penelitian yang beragam. Walaupun Anisma (2012), Masril, (2017) menemukan pengaruh positif antara profitabilitas terhadap harga saham , tetapi tidak demikian dengan kajian empiris dari Rachman dan Sutrisno, (2011) yang mendapatkan profitabilitas berpengaruh signifikan negatif terhadap harga saham pada perusahaan manufaktur yang terdaftar di Bursa Efek Indonesia. Laba per lembar saham yang secara konsep memiliki pengaruh positif terhadap harga saham telah diuji secara empiris oleh (Dewi dan Suaryana 2013), (Rachman dan Sutrisno, 2011), (Masril, 2017), akan tetapi hasil riset yang berbeda didapat oleh (Dewi dan Suaryana (2013) bahwa laba perlembar saham berpengaruh negatif terhadap harga saham.Sedangkan leverage yang secara teoritis mempunyai resiko kerugian lebih kecil ketika keadaan ekonomi merosot, namun ketika kondisi ekonomi membaik, kesempatan memperoleh laba rendah. Sebaliknya perusahaan dengan rasio leverage tinggi, beresiko menanggung kerugian yang besar ketika keadaan ekonomi merosot, tetapi mempunyai kesempatan memperoleh laba besar saat kondisi ekonomi membaik. Melihat kondisi perusahaan yang beragam maka kajian empiris yang berbeda didapat oleh Rachman dan Sutrisno (2011), Dewi dan Suaryana (2013) yang menyatakan leverage berpengaruh negative terhadap harga saham, tidak demikian dengan hasil riset Munib (2016) menemukan pengaruh leverage terhadap harga saham perusahaan menunjukkan hasil yang signifikan positif. Melalui kajian teoritis terhadap faktor eksternal yaitu; inflasi,suku bunga,nilai tukar (kurs) yang memiliki pengaruh negative terhadap harga saham juga tidak tercermin dari beberapa hasil penelitian yang beragam. Pengaruh signifikan negative inflasi terhadap harga saham di Bursa Efek Indonesia didapat melalui kajian empiris (Thobarry 2009), (Rachmawati dan Laila 2015), (Suselo, Djazuli, dan Indrawati 2015), (Thobarry (2009), (Luthfiana (2018). Namun sebaliknya pengaruh positif inflasi terhadap harga saham didapat melalui kajian empiris yang dilakukan (Alam 2017) pada pasar saham India dan 
variabel makroekonomi menunjukkan hasil bahwa hubungan antara inflasi dan harga saham ditemukan positif untuk kedua indeks NIF dan BSE. Kajian empiris Krisna dan Wirawati (2013), Sunardi, Nurmillah, dan Ula (2017),Luthfiana (2018), menemukan bahwa suku bunga tidak berpengaruh terhadap indeks harga saham gabungan di Bursa Efek Indonesia. Sedangkan kajian empris Wardani dan Andarini (2016), S. Raharjo (2020) yang menyatakan tingkat suku bunga/BI rate berpengaruh positif terhadap harga saham di Bursa Efek Indonesia. Kajian empiris yang terkait pengaruh nilai tukar (kurs) terhadap harga saham didapat memiliki pengaruh negative dibuktikan oleh (Olugbenga 2011) ,(Pujawati, Wiksuana, dan Artini 2015),(Mardiyati dan Rosalina 2013), (Luthfiana 2018), , sementara berbeda dengan temuan Wibowo (2012), Raharja (2014),Krisna dan Wirawati (2013) menemukan bahwa nilai tukar rupiah berpengaruh positif terhadap indeks harga saham bagungan di BEI.

Beberapa kajian empiris dengan hasil yang berbeda tersebut mendorong peneliti untuk menguji lebih lanjut pengaruh faktor internal dan eksternal terhadap harga saham. Perbedaan penelitian ini dengan penelitian sebelumnya terletak pada subyek penelitian, variabel dan indikator yang digunakan ,rentang waktu pengamatan,menggunakan data panel serta teknik analisis SEM_PLS. Penelitian ini menggunakan variabel laten dengan indikator tunggal yaitu profitabilitas, earning per share,leverage,inflasi,suku bunga/BI rate, nilai tukar (kurs) dan harga saham dengan subyek penelitian perusahaan Sektor Kosmetik dan Keperluan Rumah Tangga yang terdaftar di Bursa Efek Indonesia untuk periode 2011 - 2018. Berdasarkan paparan diatas penelitian ini bertujuan untuk mengetahui dan menganalisis pengaruh faktor internal perusahaan yaitu ;pengaruh profitabilitas terhadap harga saham ;pengaruh laba perlembar saham terhadap harga saham ;pengaruh leverage terhadap harga saham, untuk mengetahui dan menganalisis pengaruh faktor eksternal yakni ; pengaruh inflasi terhadap harga saham, pengaruh suku bunga terhadap harga saham;pengaruh nilai tukar (kurs) terhadap harga saham.

\section{KAJIAN PUSTAKA DAN PENGEMBANGAN HIPOTESIS \\ Pasar Modal \\ Sesuai dengan Undang-undang No 8 Tahun}

1995 bahwa pasar modal adalah kegiatan yang bersangkutan dengan penawaran umum dan perdagangan efek, perusahaan publik yang berkaitan dengan efek yang diterbitkannya, serta lembaga dan profesi yang berkaitan dengan efek. Pasar modal adalah wadah yang terorganisir berdasarkan undang-undang untuk mempertemukan antara investor sebagai pihak yang surplus dana untuk berinvestasi dalam instrumen keuangan jangka panjang" (Tandelilin 2001,13). Adanya pasar modal dapat menghimpun dana masyarakat yang nantinya bermanfaat dalam menambah modal kerja dan pengembangan usaha. Selain itu hadirnya pasar modal memberi kesempatan investor untuk mendapatkan keuntungan serta dapat meningkatkan pembangunan ekonomi nasional. Jadi pasar modal adalah tempat berbagai pihak, khususnya perusahaan menjual saham (stock) dan obligasi (bond), dengan tujuan dari hasil penjualan tersebut nantinya akan dipergunakan sebagai tambahan dana atau memperkuat modal perusahaan (Sunariyah 2003,17)

\section{Harga Saham}

Menurut (Sunariyah 2003,21) harga saham adalah harga yang terjadi di pasar bursa pada saat tertentu yang ditentukan oleh pelaku pasar dan ditentukan oleh permintaan dan penawaran saham yang bersangkutan di pasar modal. Dalam penilaian saham dikenal adanya tiga jenis nilai yaitu: nilai buku, nilai pasar dan nilai instrinsik saham" (Tandelilin, 2001,24). Apabila di pasar modal maka penilaian harga saham tergolong dalam nilai pasarnya yang jika pasar bursa tutup, harga yang dimaksud ialah closing pricenya(Anisma 2012)

\section{Profitabilitas}

Profitabilitas (profitability) menunjukkan kemampuan perusahaan untuk menghasilkan keuntungan dan mengukur tingkat efisiensi operasional dan efisiensi dalam menggunakan harta yang dimilikinya.Profitabilitas adalah hasil akhir dari sejumlah kebijakan dan keputusan yang dilakukan oleh perusahaan (Brigham, E F, dan Houston 2010,112). Profitabilitas sering juga disebut Rentabilitas yang berarti kemampuan suatu perusahaan untuk mendapatkan laba selama periode tertentu.Profitabilitas (profitability) adalah kemampuan perusahaan memperoleh laba melalui 
operasional usahanya dengan menggunakan dana aset yang dimiliki oleh perusahaan. Pengertian lain juga menyebutkan bahwa profitabilitas (profitability) menunjukkan kemampuan perusahaan untuk menghasilkan keuntungan dan mengukur tingkat efisiensi operasional dan efisiensi dalam menggunakan harta yang dimilikinya (Wardita dan Astakoni 2018)

\section{Laba Perlembar Saham/ Earning Per Share}

Riyadi (2014) Earning Per Share (EPS) menunjukkan seberapa besar keuntungan yang diberikan kepada investor dari setiap lembar saham yang dimilikinya . Secara sederhana EPS menggambarkan jumlah uang yang diperoleh untuk setiap lembar saham. Berdasarkan tingkat keberhasilan perusahaan tersebut, para investor akan memperhatikan pengaruhnya di masa yang akan datang dengan melihat prospek perusahaan yang baik (Rachman dan Sutrisno 2011).Pertumbuhan laba per lembar saham perusahaan akan sangat dipertimbangkan oleh para investor dalam membuat keputusan untuk berinvestasi.

\section{Leverage}

Solvabilitas (leverage) digambarkan untuk melihat sejauh mana asset perusahaan dibiayai oleh .hutang dibandingkan dengan modal sendiri (Weston dan Copeland 2008,77).Leverage merupakan kebijakan pendanaan yang berkaitan dengan keputusan perusahaan dalam membiayai perusahaan. Leverage dapat dipahami sebagai penaksir dari resiko yang melekat pada suatu perusahaan. Artinya, leverage yang semakin besar menunjukkan risiko investasi yang semakin besar pula. Jadi bisa dikatakan menunjukan kemampuan dari suatu perusahaan untuk memenuhi segala kewajiban finansial dari perusahaan tersebut seandainya perusahaan tersebut dilikuidasi (Sawir 2005,98) . Jadi merupakan rasio yang mengukur seberapa besar perusahaan menggunakan pendanaan yang berasal dari utang (financial leverage) (Brigham, E F, dan Houston 2010,187).

\section{Inflasi}

Kuncoro $(2001,46)$ mengatakan inflasi adalah kecenderungan dari harga untuk meningkat secara umum dan terus menerus. Inflasi merupakan suatu kondisi harga barang dan jasa yang mengalami peningkatan secara umum dan berkesinambungan. Tingkat harga yang lebih tinggi menyebabkan permintaan uang naik. Penawaran uang yang tidak berubah dan peningkatan kuantitas uang yang diminta, menyebabkan tingkat bunga naik dan hasilnya adalah penurunan belanja investasi (Case dan Ray 2007). Naiknya inflasi akan mengakibatkan barang-barang menjadi mahal dan tingkat suku bunga juga akan naik. Jika terjadi kenaikan pada barang-barang dan kemudian suku bunga naik, maka masyarakat tidak akan membelanjakan uangnya dan akan cenderung menggunakan uangnya dalam bentuk tabungan(Luthfiana 2018).

\section{Suku Bunga/BI rate}

BI Rate adalah suku bunga dengan tenor satu bulan yang diumumkan oleh Bank Indonesia secara periodik untuk jangka waktu tertentu yang berfungsi sebagai sinyal (stance) kebijakan moneter (Kurniawati 2015).BI rate adalah suku bunga kebijakan yang mencerminkan sikap atau stance kebijakan moneter yang ditetapkan oleh Bank Indonesia dan diumumkan kepada publik. BI rate diumumkan oleh dewan gubernur Bank Indonesia setiap rapat dewan gubernur bulanan dan di implementasikan pada operasi moneter yang dilakukan Bank Indonesia melalui pengelolaan likuiditas (liquidity management) di pasar uang untuk mencapai sasaran operasional kebijakan moneter.

\section{Nilai Tukar}

Menurut Permenkeu No 114/PMK. 04/2007 yang dimaksud dengan nilai tukar adalah "Harga mata uang rupiah terhadap mata uang asing". Nilai tukar mata uang adalah harga sebuah mata uang dari suatu negara yang diukur atau dinyatakan dalam mata uang negara lain (Wibowo 2012). Nilai tukar yang digunakan dalam penelitian ini adalah kurs tengah BI, hanya untuk mata uang US \$ terhadap rupiah, yang merupakan nilai tengah antara kurs jual dan kurs beli yang dikeluarkan BI. Digunakannya kurs tengah BI terhadap US \$ karena US \$ adalah mata uang utama yang digunakan dalam perdagangan valas internasional. Keadaan nilai tukar yang cenderung berubah-ubah mengakibatkan investor akan menginvestasikan dananya dalam bentuk mata uang asing dan para spekulan juga akan melakukan hal serupa dengan tujuan memperoleh keuntungan dalam kondisi yang cepat berubah . 
Pengaruh Profitabilitas terhadap Harga Saham

Tujuan jangka pendek dari perusahaan adalah mendapatkan profit dalam operasinya dengan menggunakan aktiva yang dimiliki sehingga terjadi peningkatan profitabilitas. Peningkatan profitabilitas ini mempunyai efek yang positif terhadap kinerja keuangan perusahaan. Dalam pencapaian tujuan untuk memaksimalkan nilai perusahaan maka akan direspon secara positif oleh investor sehingga permintaan saham perusahaan dapat meningkat sekaligus dapat menaikan harga saham perusahaan (Masril 2017). Beberapa hasil penelitian menemukan bahwa terdapat pengaruh signifikan positif profitabilitas terhadap harga saham didapat oleh (Subiyantoro dan Andreani 2003), (Anisma 2012). Atas dasar paparan diatas maka hipotesis yang diangkat $\mathrm{H} 1$; Profitabilitas berpengaruh signifikan positif terhadap harga saham.

\section{Pengaruh Laba Perlembar Saham terhadap Harga Saham}

Laba perlembar saham atau EPS menunjukkan seberapa besar keuntungan yang diberikan kepada investor dari setiap lembar saham yang dimilikinya. Secara sederhana EPS menggambarkan jumlah uang yang diperoleh untuk setiap lembar saham. Berdasarkan tingkat keberhasilan perusahaan tersebut, para investor akan memperhatikan pengaruhnya di masa yang akan datang dengan melihat prospek perusahaan yang baik. Apabila harga saham mencerminkan kapitalisasi dari laba yang diharapkan di masa yang akan datang, maka peningkatan laba akan meningkatkan harga saham dan total kapitalisasi pasar (Masril 2017).Konsep diatas didukung oleh hasil penelitian, Rachman dan Sutrisno, (2011),Masril, (2017) yang mendapatkan Earning per share berpengaruh signifikan positif terhadap harga saham pada perusahaan manufaktur yang terdaftar di BEI. Berdasarkan paparan diatas maka hipotesis yang diangkat $\mathrm{H} 2$; Earning per share berpengaruh signifikan positif terhadap harga saham.

\section{Pengaruh Leverage terhadap Harga Saham}

Leverage merupakan rasio solvabilitas yang digunakan untuk mengukur kemampuan modal sendiri perusahaan untuk dijadikan jaminan semua hutang perusahaan (Sartono 2010,225). Perusahaan dengan leverage rendah akan mempunyai resiko kerugian lebih kecil ketika keadaan ekonomi merosot, namun ketika kondisi ekonomi membaik, kesempatan memperoleh laba juga rendah. Sebaliknya perusahaan dengan rasio leverage tinggi, beresiko menanggung kerugian yang besar ketika keadaan ekonomi merosot, tetapi mempunyai kesempatan memperoleh laba besar saat kondisi ekonomi membaik.Beberapa temuan riset yang sudah menguji pengaruh leverage terhadap harga saham perusahaan menunjukkan hasil yang negative (Rachman dan Sutrisno (2011), Dewi dan Suaryana (2013) .Berdasarkan paparan diatas maka hipotesis yang diangkat yaitu H3: Leverage berpengaruh negatif terhadap harga saham.

\section{Pengaruh Inflasi terhadap Harga Saham}

Tandelilin (2001:343) inflasi menyebabkan konsumsi riil masyarakat berkurang karena nilai uang yang mereka pegang berkurang kemudian masyarakat akan mengurangi konsumsi mereka atas barang/jasa yang dihasilkan perusahaan. Pada kondisi demikian otomatis pendapatan perusahaan ikut menurun dan memengaruhi keuntungan yang didapatnya selanjutnya berpengaruh pada harga saham perusahaan tersebut. Harga saham yang kian menurun akan memengaruhi niat investor untuk membeli saham perusahaan tersebut yang pada akhirnya juga berpengaruh pada indeks harga saham. Penelitian yang mendukung mengenai variabel inflasi mempunyai pengaruh negatif terhadap indeks harga saham adalah penelitian yang dilakukan oleh (Thobarry 2009), (Rachmawati dan Laila 2015), (Suselo, Djazuli, dan Indrawati 2015),(Thobarry 2009). Dari paparan tersebut di atas dapat diajukan hipotesis berikut : H4 : Inflasi berpengaruh negative terhadap harga saham

\section{Pengaruh Suku Bunga terhadap Harga Saham}

BI Rate adalah suku bunga kebijakan yang ditetapkan oleh bank Indonesia dan diumumkan kepada publik, melalui pertimbangan faktor-faktor lain dalam perekonomian.Naiknya suku bunga kredit akan mempengaruhi permintaan akan barang/jasa yang nantinya akan mempengaruhi kinerja keuangan perusahaan yang terdaftar pada pasar saham (Luthfiana 2018). Kajian empiris dari Krisna dan Wirawati (2013) Sunardi, Nurmillah, dan Ula (2017),(Luthfiana 2018), menemukan 
bahwa suku bunga/BI rate berpengaruh negative terhadap indeks harga saham gabungan di BEI.Dari paparan tersebut diatas dapat diajukan hipotesis berikut :H5 : Suku bunga / BI Rate berpengaruh negative terhadap harga saham.

\section{Pengaruh Nilai Tukar terhadap Harga Saham}

Menurut Thobarry (2009) kurs dollar terhadap rupiah berpengaruh positif terhadap ekonomi dan pasar modal, sebaliknya kurs dollar terhadap rupiah berpengaruh negative. Melemahnya rupiah akan menyebabkan pasar modal dalam negeri kurang menarik karena adanya resiko nilai tukar yang menyebabkan penurunan nilai investasi dan mempunyai hubungan negatif terhadap return saham. Sebaliknya, hubungan antara nilai tukar dollar terhadap rupiah bisa saja berpengaruh positif bila investor berasal dari luar negeri dan menggunakan mata uang asing sehingga semakin terdepresiasinya mata uang rupiah akan menyebabkan investor luar cenderung melepas mata uang asingnya untuk membeli saham yang harganya turun karena pengaruh kurs mata uang.Penelitian yang dilakukan (Olugbenga 2011) menunjukkan hasil bahwa nilai tukar memberikan dampak negative terhadap harga saham di Nigeria. Kajian empirs Luthfiana (2018), menemukan bahwa nilai tukar/kurs berpengaruh signifikan negative terhadap harga saham. Hasil uji empiris yang dilakukan oleh Pujawati, Wiksuana, dan Artini (2015),Mardiyati dan Rosalina (2013) yang mengungkapkan bahwa nilai tukar memiliki pengaruh negatif terhadap harga saham.Dari paparan tersebut di atas dapat diajukan hipotesis berikut : H6 : Nilai tukar (Kurs) berpengaruh negative terhadap harga saham.

\section{METODE PENELITIAN}

\section{Populasi, Sampel dan Pengumpulan Data}

Populasi dalam studi ini adalah perusahaan manufaktur sektor kosmetik dan keperluan rumah tangga yang terdaftar di Bursa Efek Indonesia (BEI) periode 2011-2018. Pengambilan sampel dilakukan secara purposive dengan kriteria yang telah ditetapkan sebelumnya yaitu; (1) Perusahaan manufaktur sektor kosmetik dan keperluan rumah tangga yang terdaftar di BEI periode 2011-2018, (2) Perusahaan manufaktur sektor kosmetik dan keperluan rumah tangga yang melaporkan laporan keuangan yang berakhir per 31 Desember 20112018 Berdasarkan kriteria vang ditetapkan maka studi ini didasarkan pada data panel dengan melibatkan sebanyak 4 perusahaan selama 8 tahun laporan sehingga didapat jumlah sampel penelitian sebanyak 4 × $8=32$ observasi.Pengumpulan data dilakukan melalui situs masing-masing perusahaan untuk data primer dan dikumpulkan juga melalui situs resmi BI (www.bi.go.id) dan situs resmi BPS (www.bps.go.id).

\section{Definisi Operasional dan Pengukuran Variabel}

Variabel yang digunakan dalam penelitian ini adalah variabel endogen dan variabel eksogen.Variabel endogen (endogenous variable) merupakan variabel yang dipengaruhi atau yang menjadi akibat, karena adanya variabel eksogen.Variabel eksogen merupakan variabel yang mempengaruhi atau yang menjadi sebab perubahannya atau timbulnya variabel endogen (Sugiyono 2007,54). Variabel endogen dalam penelitian ini adalah Harga Saham . Sedangkan variabel eksogen dalam penelitian ini adalah profitabilitas, laba per lembar saham, leverage, suku bunga/BI rate, inflasi dan nilai tukar.

\section{Harga Saham (Y)}

Harga saham adalah nilai dari suatu saham yang diperdagangkan, Harga penutupan adalah harga yang diminta oleh penjual atau pembeli pada saat akhir hari bursa (Halim 2007,16). Harga saham yang dimaksudkan dalam studi ini adalah harga penutupan (close price).

\section{Profitabilitas (X1)}

Profitabilitas merupakan kemampuan perusahaan memperoleh laba melalui operasional usahanya dengan menggunakan dana aset yang dimiliki oleh perusahaan. Pengukuran profitabilitas dalam penelitian ini diukur menggunakan Return On Equity (ROE). ROE merupakan rasio pengukuran yang menunjukkan seberapa besar pendapatan yang diterima bagi pemegang saham terhadap investasi yang ditanamkan (P. I. M. Astakoni et al. 2019), (I. M. P. Astakoni and Nursiani 2020).

\section{Laba Per Lembar Saham/EPS (X2).}

Laba per lembar saham/earning per share merupakan perbadingan antara laba bersih dengan jumlah saham yang beredar (Brigham 2012) (Riyadi 2014) 


\section{Leverage(X3)}

Leverage adalah suatu tingkat kemampuan perusahaan dalam menggunakan aset dan atau dana yang mempunyai beban tetap (hutang dan atau saham istimewa). Leverage dalam penelitian ini diproksi dengan menggunakan indikator tunggal Debt to Equity ratio (DER) yang merupakan perbandingan hutang dengan modal (equity) perusahaan (Swaputra et al. 2018), (I. M. P. Astakoni and Utami 2019), (I. M. P. Astakoni and Wardita 2020).

\section{Inflasi(X4)}

Inflasi didefinisikan sebagai kenaikan harga-harga secara keseluruhan dan terus menerus. Dalam studi ini tingkat inflasi didasarkan pada nilai rata-rata inflasi dalam 1 tahun (Kumalasari, Hidayat, and Azizah 2016)

\section{Suku Bunga/BI rate (X5)}

BI rate adalah suku bunga kebijakan yang mencerminkan sikap atau stance kebijakan moneter yang ditetapkan oleh Bank Indonesia dan diumumkan kepada publik. BI rate diumumkan oleh dewan gubernur Bank Indonesia setiap rapat dewan gubernur bulanan dan di implementasikan pada operasi moneter yang dilakukan Bank Indonesia (Kurniawati 2015)

\section{Nilai Tukar(X6)}

Nilai tukar atau kurs (foreign exchange rate) adalah harga mata uang yang berbeda di suatu negara relatif terhadap mata uang negara lain (Sunariyah 2003,89). Dalam studi ini nilai tukar yang dimaksud adalah kurs tengah Rp/USD. Kurs tengah BI, hanya untuk mata uang US \$ terhadap rupiah, yang merupakan nilai tengah antara kurs jual dan kurs beli yang dikeluarkan BI. (Halim 2007,16), (Anisma 2012) (Wibowo 2012).

Berdasarkan definisi operasional dan pengukuran variabel, maka dapat disajikan dalam bentuk tabel 1 berikut;

\section{Tabel 1}

Sifat, Jenis ,Simbol dan Proksi Variabel

\begin{tabular}{|c|c|c|c|c|}
\hline $\begin{array}{c}\text { Sifat Variabel } \\
\text { Variabel Eksogen }\end{array}$ & Jenis Variabel & Simbol & Proksi & Sumber Acuan \\
\hline \multirow[t]{8}{*}{ Variabel Eksogen } & Profitabilitas & $\mathrm{X}_{1}$ & Return on & I. M.P Astakoni et al. (2019), I. M. \\
\hline & & & Equity (ROE) & P. Astakoni and Nursiani (2020) \\
\hline & Earning Per-Share & $\mathrm{X} 2$ & EPS & Riyadi (2014) \\
\hline & Leverage & $\mathrm{X} 3$ & Debt to Equity & I. M. P. Astakoni and Utami (2019) \\
\hline & Inflasi & $\mathrm{X} 4$ & Rata-rata & Kumalasari, Hidayat, and Azizah \\
\hline & & & Inflasi & (2016) \\
\hline & Suku Bunga & $\mathrm{X} 5$ & $\mathrm{BI}$ rate & Kurniawati (2015) \\
\hline & Nilai Tukar (Kurs) & X6 & $\begin{array}{l}\text { Kurs Tengah } \\
\text { Rp/USD }\end{array}$ & $\begin{array}{c}\text { Wibowo (2012),Kumalasari, Hidayat, } \\
\text { and Azizah (2016) }\end{array}$ \\
\hline Variabel Endogen & Harga saham & $\mathrm{Y}$ & Closing Price & Halim (2007,16), Anisma (2012) \\
\hline
\end{tabular}

\section{Teknik Analisis Data}

Analisis Statistik Deskriptif

Statistik deskriptif adalah statistik yang digunakan untuk menganalisis data dengan cara mendeskripsikan data yang didapat tanpa bermaksud membuat kesimpulan yang berlaku umum (Sugiyono 2007,54). Pada analisis ini yaitu mendeskripsikan variabel yang terdapat dalam penelitian menggunakan bantuan program spss ver 22 .

Analisis Statistik Inferensial
Pada fenomena bisnis, sebuah variabel endogen dapat dipengaruhi oleh beberapa variabel eksogen, dan variable eksogen yang lain juga mampu mempengaruhi variabel endogen secara sekaligus,sehingga mengakibatkan model penelitian menjadi sangat rumit (Suliyanto 2011,65), (Ferdinand 2014,98). Dalam penelitian ini analisis data menggunakan pendekatan Partial Least Square (PLS). PLS adalah model persamaan Structural Equation Modeling (SEM) yang berbasis komponen atau varian. PLS merupakan metode analisis yang powerfull (Ghozali 2011,88) karena 
tidak didasarkan pada banyak asumsi.Dalam PLS path modeling terdapat dua model yaitu outler model dan inner model.Perlu diketahui untuk analisis regresi berganda dengan variabel obseved dengan pendekatan PLS tidak perlu melakukan pengukuran model (measurement model), sehingga langsung dilakukan estimasi model struktural (Latan and Ghozali 2012,304),(Budhiasa 2016;36)

\section{Outler Model (Measurement Model)}

Terkait dengan indikator-indikator yang membentuk variabel laten dalam penelitian ini bersifat formatif, maka evaluasi model pengukuran (measurement model/outer model), dievaluasi dengan substantive contennya yaitu dengan membandingkan besarnya weight dan melihat signifikansi dari ukuran weight tersebut. Signifikansi weight indikator formatif diperoleh melalui prosedur boostrapping (Latan and Ghozali 2012,306)

\section{Inner Model (Structural Model).}

Evaluasi model struktural (Structural Model/Inner Model) merupakan pengujian terhadap hipotesis penelitian. Apabila diperoleh nilai tstatistik lebih besar dari 1,96 dapat disimpulkan pengaruh antar variabel signifikan demikian sebaliknya.

\section{HASIL DAN PEMBAHASAN}

\section{Hasil Penelitian}

Analisis Statistik Deskriptif

Secara deskripsi variabel profitabilitas (X1), earning per share (X2), leverage (X3), inflasi (X4), tingkat bunga/BI rate (X5), dan nilai tukar Rp/USD (Kurs) serta harga saham (Y) dari masing-masing variabel tersebut, maka berikut ini disajikan hasil sebagai berikut

Tabel 2

Statistik Deskriptif Variabel Penelitian

\begin{tabular}{|l|c|c|c|c|c|}
\hline \multicolumn{1}{|c|}{ Variabel Pnelitian } & $\mathrm{N}$ & Minimum & Maximum & Mean & Std. Deviation \\
\hline Profitabilitas (X1) & 32 & 1,3585 & 0,0028 & 0,3663 & 0,5021 \\
Earning Per-Share (X2) & 32 & 7,0867 & 1,0986 & 4,7561 & 2,0699 \\
Leverage (X3) & 32 & 1,9084 & 0,0977 & 0,4264 & 0,4138 \\
Inflasi (X4) & 32 & 8,3600 & 3,0200 & 4,7400 & 2,1572 \\
Suku Bunga (X5) & 32 & 7,7500 & 4,2500 & 6,1875 & 1,2427 \\
Nilai Tukar (X6) & 32 & 9,5806 & 9,1125 & 9,4073 & 0,1635 \\
Harga Saham (Y) & 32 & 10,9313 & 4,8363 & 7,7254 & 2,2874 \\
Valid N (listwise) & 32 & & & & \\
\hline
\end{tabular}

Sesuai Tabel 2, dapat dijelaskan variabel profitabilitas (X1) memiliki rata-rata (mean) sebesar 3,3663. dengan standar deviasi sebesar 0,5021. Nilai tertinggi (maximum ) sebesar 1,3585 dan nilai terendah (minimum) 0,0028. Pada variabel laba per-lembar saham (X2) memiliki ratarata (mean) sebesar 4,7561, dengan standar deviasi sebesar 2,0699.Nilai tertinggi (maximum) 7,0867 dan nilai terendah (minimum) 1,0986. Pada variabel leverage (X3) didapat nilai rata-rata (mean) sebesar 0,4264, dengan standar deviasi sebesar 0,4138 dengan nilai tertinggi (maximum) sebesar 1,9084 dan nilai terendah 0,0977. Pada variabel inflasi (X4) didapat nilai rata-rata (mean) sebesar 4,7400, dengan standar deviasi sebesar 2,1572 dengan nilai tertinggi (maximum) sebesar 8,3600 dan nilai terendah (minimum) 3,0200. Pada variabel suku bunga (X5) didapat nilai rata-rata (mean) sebesar 6.1875. dengan standar deviasi sebesar 1,2427 dengan nilai tertinggi (maximum) sebesar 7,7500 dan nilai terendah (minimum) 4,2500. Pada variabel nilai tukar (X6) didapat nilai rata-rata (mean) sebesar 9,4073, dengan standar deviasi sebesar 0,1635 dengan nilai tertinggi (maximum) sebesar 9,5806 dan nilai terendah (minimum) 9,1125. Pada variabel harga saham (Y) didapat nilai rata-rata (mean) sebesar 7,7254, dengan standar deviasi sebesar 2,2874 dengan nilai tertinggi (maximum) sebesar 10,9313 dan nilai terendah (minimum) 4,8363.

\section{Analisis Statistik Infrensial}

Dalam studi ini, oleh karena menggunakan pendekatan indikator tunggal dan bersifat formatif maka hanya dilakukan uji inner model. Uji inner model dipergunakan untuk mengevaluasi hubungan antar konstruk laten seperti yang telah dihipotesiskan dalam penelitian ini. Berdasarkan 
hasil analisis dengan PLS, didapatkan hasil dari Inner Weight menunjukkan bahwa nilai perusahaan, dipengaruhi oleh keputusan investasi,leverage, profitabilitas dan ukuran perusahaan (Size), yang kesemua ini akan djelaskan pada pengujian hipotesis. Melalui Tabel 3 memberikan gambaran output estimasi untuk pengujian model struktural dimana hasil yang diharapkan adalah Ho ditolak atau nilai sig $<0,05$ (atau t-statistic > 1,96)

Tabel 3

Path Analysis dan Pengujian Hipotesis

\begin{tabular}{|c|c|c|c|c|c|c|}
\hline Hubungan Konstruk & $\begin{array}{c}\text { Original } \\
\text { Sample } \\
(\mathbf{O})\end{array}$ & $\begin{array}{c}\text { Sample } \\
\text { Mean } \\
(\mathbf{M})\end{array}$ & $\begin{array}{c}\text { Standard } \\
\text { Deviation } \\
(\text { STD })\end{array}$ & $\begin{array}{c}\text { T } \\
\text { Statistics } \\
(\mathbf{O} / \text { STEV) }\end{array}$ & P-Value & Keterangan \\
\hline $\begin{array}{c}\text { Profitabilitas } \rightarrow \text { Harga } \\
\text { Saham }\end{array}$ & 0,655 & 0,661 & 0,298 & 2,200 & 0,028 & Signifikan \\
\hline $\begin{array}{c}\text { Laba Per Lembar Saham } \\
\rightarrow \text { Harga Saham }\end{array}$ & 0,458 & 0,510 & 0,162 & 2,830 & 0,005 & Signifikan \\
\hline Leverage $\rightarrow$ Harga Saham & $-0,095$ & $-0,123$ & 0,276 & 0,345 & 0,730 & $\begin{array}{c}\text { Tidak } \\
\text { Signifikan }\end{array}$ \\
\hline Inflasi $\rightarrow$ Harga Saham & $-0,041$ & $-0,030$ & 0,104 & 0,394 & 0,694 & $\begin{array}{c}\text { Tidak } \\
\text { Signifikan }\end{array}$ \\
\hline Suku Bunga $\rightarrow$ Harga Saham & $-0,038$ & $-0,025$ & 0,130 & 0,290 & 0,772 & $\begin{array}{c}\text { Tidak } \\
\text { Signifikan }\end{array}$ \\
\hline Nilai Tukar $\rightarrow$ Harga Saham & 0,006 & $-0,006$ & 0,147 & 0,039 & 0,969 & $\begin{array}{c}\text { Tidak } \\
\text { Signifikan }\end{array}$ \\
\hline
\end{tabular}

Pada sisi lain hasil perhitungan ketepatan model dengan melihat koefisien determinasi yang disesuaikan (R Square Adjusted) bahwa kontribusi model untuk menjelaskan hubungan struktural dari ketujuh variabel yang diteliti adalah sebesar 0,577 (atau $57,70 \%$ ), atau dengan kata lain, informasi yang terkandung dalam data $57,70 \%$ dapat dijelaskan oleh model tersebut.

\section{Pembahasan}

Pengaruh Profitabilitas terhadap Harga Saham

Hipotesis pertama; yang menyatakan bahwa terdapat pengaruh signifikan positif antara profitabilitas terhadap harga saham.Hasil analisis menemukan koefisien sebesar 0,655 (positif) dengan nilai t hitung 2,200 $(>1,96)$ atau nilai $\mathrm{p}$ value sebesar $0,028 \quad(\mathrm{p}<0,05)$. Ini berarti profitabilitas berpengaruh signifikan positif terhadap harga saham sehingga hipotesis dapat diterima. Beberapa hasil penelitian yang sejalan dengan riset ini juga menemukan bahwa terdapat pengaruh signifikan positif profitabilitas terhadap harga saham didapat oleh (Subiyantoro dan Andreani 2003) (Anisma 2012). Berbeda dengan kajian empiris Masril, (2017) mendapatkan profitabilitas berpengaruh tidak signifikan positif terhadap harga saham pada perusahaan manufaktur yang terdaftar di BEI. Bahkan hasil riset Rachman and Sutrisno, (2011) yang mendapatkan profitabilitas berpengaruh signifikan negatif terhadap harga saham pada manufaktur yang terdaftar di Bursa Efek Indonesia. Hasil riset Dewi and Suaryana (2013) mendapatkan ada pengaruh signifikan negative antara laba per lembar saham terhadap harga saham.

\section{Pengaruh Laba Perlembar Saham terhadap Harga Saham}

Hipotesis kedua; yang menyatakan bahwa terdapat pengaruh signifikan positif antara laba per lembar saham terhadap harga saham. Hasil analisis menemukan koefisien sebesar 0,458 (positif) dengan nilai t hitung $2,830(>1,96)$ atau nilai $\mathrm{p}$ value sebesar $0,005(p<0,05)$. Ini berarti laba per lembar saham berpengaruh signifikan positif terhadap harga saham sehingga hipotesis dapat diterima. Temuan ini mendukung hasil riset Marlina (2013),Dewi and Suaryana (2013), Rachman and Sutrisno, (2011),Masril, (2017) yang mendapatkan earning per share (EPS) berpengaruh signifikan positif terhadap harga saham pada perusahaan manufaktur yang terdaftar di BEI. Berbeda dengan hasil riset Raharjo (2013), yang mendapatkan terdapat pengaruh positif tidak 
signifikan EPS terhadap harga saham. Kajian empiris Subiyantoro dan Andreani (2003) yang mendapatkan tidak terdapat pengaruh laba per lembar saham/EPS terhadap harga saham

\section{Pengaruh Leverage terhadap Harga Saham}

Hipotesis ketiga; yang menyatakan bahwa terdapat pengaruh signifikan negative antara leverage terhadap harga saham.Hasil analisis menemukan koefisien sebesar $-0,095$ (negatif) dengan nilai $\mathrm{t}$ hitung $0,345(<1,96)$ atau nilai $\mathrm{p}$ value sebesar $0,730(p>0,05)$. Ini berarti leverage tidak berpengaruh terhadap harga saham sehingga hipotesis tidak dapat diterima. Hasil riset ini sejalan dengan temuan riset yang sudah menguji pengaruh leverage terhadap harga saham perusahaan menunjukkan hasil yang tidak signifikan negative (Rachman and Sutrisno 2011)(Suselo, Djazuli, and Indrawati 2015). Berbeda dengan kajian empris Dewi and Suaryana (2013) mendapatkan pengaruh leverage terhadap harga saham perusahaan menunjukkan hasil yang signifikan negative. Bahkan hasil riset Munib (2016) menemukan pengaruh leverage terhadap harga saham perusahaan menunjukkan hasil yang signifikan positif.

\section{Pengaruh Inflasi terhadap Harga Saham}

Hipotesis keempat; yang menyatakan bahwa terdapat pengaruh signifikan negative antara inflasi terhadap harga saham.Hasil analisis menemukan koefisien sebesar $-0,041$ (negatif) dengan nilai $t$ hitung $0,394(<1,96)$ atau nilai p-value sebesar $0,694(\mathrm{p}>0,05)$. Ini berarti inflasi tidak berpengaruh terhadap harga saham sehingga hipotesis dapat diterima.Penelitian ini mendukung mengenai variabel inflasi mempunyai pengaruh negatif terhadap indeks harga saham adalah penelitian yang dilakukan oleh (Thobarry 2009) (Rachmawati and Laila 2015), (Suselo, Djazuli, and Indrawati 2015), Luthfiana (2018). Berbalik dengan kajian empris yang dilakukan (Alam 2017) untuk mengetahui hubungan antara pasar saham india dan variabel makroekonomi menunjukkan hasil bahwa hubungan antara inflasi dan harga saham ditemukan positif untuk kedua indeks NIF dan BSE.

\section{Pengaruh Suku Bunga terhadap Harga Saham}

Hipotesis kelima; yang menyatakan bahwa terdapat pengaruh signifikan negative antara tingkat suku bunga terhadap harga saham.Hasil analisis menemukan koefisien sebesar $-0,038$ (negatif) dengan nilai t hitung $0,290(<1,96)$ atau nilai $p$ value sebesar $0,772(\mathrm{p}>$

$0,05)$. Ini berarti suku bunga acuan BI tidak berpengaruh terhadap harga saham sehingga hipotesis tidak dapat diterima. Hasil riset ini sejalan dengan kajian empiris dari Krisna and Wirawati (2013) Sunardi, Nurmillah, and Ula (2017) menemukan bahwa suku bunga/BI rate tidak berpengaruh terhadap indeks harga saham gabungan di BEI, Demikian juga halnya kajian empiris (Luthfiana 2018), menemukan bahwa suku bunga tidak berpengaruh terhadap harga saham.Sementara hasil studi ini tidak mendukung kajian empris Wardani and Andarini (2016), S. Raharjo (2020) yang menyatakan tingkat suku bunga/BI rate berpengaruh positif terhadap harga saham di Bursa Efek Indonesia.

\section{Pengaruh Nilai Tukar terhadap Harga Saham}

Hipotesis keenam; yang menyatakan bahwa terdapat pengaruh signifikan negative antara nilai tukar/kurs terhadap harga saham. Hasil analisis menemukan koefisien sebesar 0,006 (positif) dengan nilai t hitung $0,039(<1,96)$ atau nilai $\mathrm{p}$ value sebesar 0,969 (p>0,05). Ini berarti nilai tukar /kurs tidak berpengaruh terhadap harga saham sehingga hipotesis tidak dapat diterima. Hasil uji empiris ini sejalan dengan yang dilakukan oleh (Pujawati, Wiksuana, and Artini 2015),(Mardiyati and Rosalina 2013) yang mengungkapkan bahwa nilai tukar memiliki pengaruh negatif terhadap harga saham. Penelitian yang dilakukan (Olugbenga 2011) menunjukkan hasil bahwa nilai tukar memberikan dampak negative terhadap harga saham di Nigeria. Kajian empirs (Luthfiana 2018), menemukan bahwa nilai tukar/kurs berpengaruh signifikan negative terhadap harga saham. Sementara hasil studi ini berlawanan dengan kajian empris dari Krisna and Wirawati (2013) menemukan bahwa nilai tukar rupiah berpengaruh signifikan positif terhadap indeks harga saham bagungan di BEI. Wibowo (2012), Raharja (2014) dalam penelitiannya menemukan adanya pengaruh positif nilai tukar terhadap harga saham.

\section{SIMPULAN DAN SARAN Simpulan}

Hasil perhitungan ketepatan model dengan melihat koefisien determinasi menjelaskan 
hubungan struktural dari ketujuh variabel yang diteliti adalah sebesar 0,577 (atau 57,70\%), atau dengan kata lain, informasi yang terkandung dalam data $57,70 \%$ dapat dijelaskan oleh model tersebut.Hasil pengujian hipotesis pertama; yang menyatakan bahwa terdapat pengaruh signifikan positif antara profitabilitas terhadap harga saham dapat diterima. Hipotesis kedua; yang menyatakan bahwa terdapat pengaruh signifikan positif antara laba per lembar saham terhadap harga saham dapat diterima. Hipotesis ketiga; yang menyatakan bahwa terdapat pengaruh signifikan negative antara leverage terhadap harga saham tidak dapat diterima. Hipotesis keempat; yang menyatakan bahwa terdapat pengaruh signifikan negative antara inflasi terhadap harga saham tidak dapat diterima. Hipotesis kelima; yang menyatakan bahwa terdapat pengaruh signifikan negative antara tingkat suku bunga terhadap harga saham tidak dapat diterima. Hipotesis keenam; yang menyatakan bahwa

\section{DAFTAR PUSTAKA}

Alam, Naushad. 2017. "Analysis Of The Impact Of Select Macroeconomic Variables on The Indian Stock Market: A Heteroscedastic Cointegration Approach." Business and Economic Horizons 13 (1): 119-27. https://doi.org/10.15208/beh.2017.09.

Anisma, Yuneita. 2012. "Faktor-Faktor Yang Mempengaruhi Harga Saham Perusahaan Perbankan Yang Listing Di Bursa Efek Indonesia (BEI)." Jurnal Sosial Ekonomi Pembangunan 2 (5): 144-65.

Astakoni, I Made Purba, and Ni Putu Nursiani. 2020. "Efek Intervening Struktur Modal Pada Pengaruh Ukuran Perusahaan Terhadap Profitabilitas." Krisna Kumpulan Riset Akuntansi 11 (2): 137-47.

Astakoni, I Made Purba, and Ni Made Satya Utami. 2019. "Determinan Kebijakan Dividen Perusahaan Manufaktur." Jurnal Riset Akuntansi Juara 9 (2): 81-91.

Astakoni, I Made Purba, and I Wayan Wardita. 2020. "Keputusan Investasi, Leverage , Profitabilitas , Dan Ukuran Perusahaan Sebagai Faktor Penentu Nilai Perusahaan Manufaktur." Wacana Ekonomi (Jurnal Ekonomi,Bisnis Dan Akuntansi) 19 (1): 10 23.

Astakoni, Purba I Made, Ida Bagus Swaputra, Sri terdapat pengaruh signifikan negative antara nilai tukar/kurs terhadap harga saham tidak dapat diterima.

\section{Saran-saran}

Atas dasar hasil analisis sebelumnya , maka diharapkan untuk penelitian selanjutnya agar bisa menguji variabel/konstruk lain yang diduga berpengaruh terhadap harga saham perusahaan baik faktor fundamental maupun makro ekonomi yang lain. Selain itu penelitian selanjutnya disarankan memperpanjang periode penelitian dan memperluas populasi dengan memasukkan sektor industri manufaktur yang yang lain untuk menghindari kemungkinan adanya bias data penelitian. Dasi sisi analisis karena studi ini menggunakan data panel, maka diharapkan bisa dilanjutkan untuk bisa membandingkan model data seimbang dan data tidak seimbang dalam kajian yang lebih spesifik..

Tjok Istri Harwathy, and Mela Ni Putu Ratini. 2019. "Dividen Policy And Company Growth As Determinants Of Profitability." International Journal of Sustainability Education And Global Creative Economic (IJSEGCE) 2 (1): 28-33.

Brigham, E F, dan Houston, J F. 2010. DasarDasar Manajemen Keuangan. Kesepuluh. Jakarta : Penerbit Salemba Empat.

Brigham, F. Eugene dan Joel Fhouston. 2012. Fundamentals of Financial Management ( Dasar-Dasar Manajemen Keuangan ). 1sted. Jakarta: Salemba Empat.

Budhiasa, Sudjana. 2016. Analisis Statistik Multivariate Dengan Aplikasi SEM PLS SmartPLS 3.2.6. Edited by Jiwa Atmaja. Edisi Pert. Denpasar: Udayana University Press.

Case, Karl E, and C Fair. Ray. 2007. PrinsipPrinsip Ekonomi. Jilid 2. Diterjemahkan Oleh: H. Wibi Hardani Dan Devri Barnadi. Edisi Kede. Jakarta: Erlangga.

Dewi, Putu Dina Aristya, and I G N A Suaryana. 2013. "Pengaruh EPS, DER, Dan PBV Terhadap Harga Saham.” E-Jurnal Akuntansi 4 (1): 215-29.

Ferdinand, Augusty. 2014. Structural Equation Modeling. 5thed. semarang: Badan Penerbit Universitas Diponegoro Semarang. 
Ghozali, Imam. 2011. Aplikasi Analisis Multivariate Dengan Program SPSS 19. Edited by Prayogo P.Harto. V. Semarang: Badan Penerbi Univ Diponogoro.

Halim, Abdul. 2007. Akuntansi Sektor Publik (Akuntansi Keuangan Daerah). Edisi Revi. Jakarta: Salemba Empat.

Husnan, Suad, and Enny Pudjiastuti. 2010. DasarDasar Manajemen Keuangan, Jilid I. Yogyakarta: UPP - AMP YKPN.

Krisna, Anak Agung Gde Aditya, and Ni Gusti Putu Wirawati. 2013. "Pengaruh Inflasi, Nilai Tukar Rupiah, Suku Bunga SBI Pada Indeks Harga Saham Gabungan." E-Jurnal Akuntansi Universitas Udayana 3 (2): 42135.

Kumalasari, Rindra, Raden Rustam Hidayat, and Devi Farah Azizah. 2016. "Pengaruh Nilai Tukar, BI Rate,Tingkat Inflasi Dan Pertumbuhan Ekonomi Terhadap Indeks Harga Saham Gabungan (Studi Pada Indeks Harga Saham Gabungan Di BEI Periode Juli 2005-Juni 2015).” Jurnal Administrasi Bisnis JAB Universitas Brawijaya Universitas Brawijaya 34 (1): 130-37.

Kuncoro, Mudrajad. 2001. Manajemen Keuangan Internasional, Pengantar Ekonomi Dan Bisnis Global. 2nded. Yogyakarta: Badan Penerbit Fakultas Ekonomi (BPFE).

Kurniawati, Emi. 2015. "Analisis Pengaruh Nilai Tukar (Kurs) ,Inflasi, BI Rate Dan Jumlah Uang Beredar Terhadap Harga Saham Pada Peerusahaan Perbankan Yang Terdaftar Di Bursa Efek Indonesia Periode 2013." Fakultas Ekonomi Dan Bisnis Univ Muhammadiah Surakarta. Univ Muhammadiah. https://doi.org/10.1145/3132847.3132886.

Latan, Hengky, and Imam Ghozali. 2012. Partial Least Squares Konsep Teknik Dan Aplikasi SmartPLS 2.0 Untuk Penelitian Empiris. Edited by Harto Prayogo P. Semarang: Badan Penerbit Univ Diponogoro.

Luthfiana, Hilmia. 2018. "Pengaruh Nilai Tukar, Tingkat Suku Bunga Dan Inflasi Terhadap Indeks Harga Saham Sektor Properti Yang Terdaftar Di Bursa Efek Indonesia." Tesia Program Pascasarjana Fakultas Ekonomi, UII Yogyakarta. https://doi.org/10.1017/CBO9781107415324 .004 .
Mardiyati, Umi, and Ayi Rosalina. 2013. "Analisis Pengaruh Nilai Tukar, Tingkat Suku Bunga Dan Inflansi Terhadap Indeks Harga Saham." Jurnal Riset Manajemen Sains Indonesia (JRMSI) 4 (1): 1-15.

Marlina, Tri. 2013. "Pengaruh Earning Per Share, Return On Equity,Debt to Equity Ratio Dan Size Terhadap Price to Book Value." Jiakes,Jurnal Ilmiah Akuntansi Kesatuan 1 (1): 59-72.

Masril, Firmansyah. 2017. "Pengaruh Pertumbuhan Perusahaan, Total Asset Turnover, Return on Investment, Earning Per Share Terhadap Harga Saham (Studi Perusahaah Manufaktur Di Bei)." AJIE - Asian Journal of Innovation and Entrepreneurship 2 (2): 110-21. https://doi.org/10.20885/ajie.vol2.iss2.art3.

Munib, Muhammad Fatih. 2016. "Pengaruh Kurs Rupiah, Inflasi Dan BI RateTerhadap Harga Saham Perusahaan Sektor Perbankan Di Bursa Efek Indonesia." eJournal Administrasi Bisnis 4 (4): 947-59.

Olugbenga, Adaramola Anthony. 2011. "The Impact of Macroeconomic Indicators on Stock Prices In Nigeria." Developing Country Studies 1 (2): 321-32. https://doi.org/10.1108/15265940910980632

Pujawati, Putu Eka, I Gusti Bagus Wiksuana, and Luh Gede Sri Artini. 2015. "Pengaruh Nilai Tukar Rupiah Terhadap Return Saham Dengan Profitabilitas Sebagai Variabel Intervening." E-Jurnal Ekonomi Dan Bisnis Universitas Udayana 4 (4): 220-42.

Rachman, Alwi Abdul, and Sutrisno. 2011. "Analisis Pengaruh Faktor-Faktor Fundamental Terhadap Harga Saham Perusahaan Manuaktur." In Peran Perbankan Syariah Dalam Penguatan Kapasitas UMKM Menuju Kemandirian Ekonomi Nasional Seminar Nasional Dan Call for Papers Sancall 2013, 282-92. Yogyakarta: Fakultas Ekonomi UII Yogyakarta.

Rachmawati, Martien, and Nisful Laila. 2015. "Faktor Makro Ekonomi Yang Mempengaruhi Pergerakan Harga Saham Pada Indeks Saham Syariah Indonesia (ISSI) Di Bursa Efek Indonesia (BEI).” Jurnal Ekonomi Syariah Teori Dan Terapan 2 (11): 928-42. 
Raharja, David Tri Rachmadhanto. 2014. "Analisis Pengaruh Faktor Fundamental Perusahaan Dan Kondisi Ekonomi Makro Terhadap UnderPricing Umum Perdana (Studi Empiris Pada Perusahaan Go Publik Yang Terdaftar Di BEI Pada Tahun 2008-2011)." Diponegoro Journal Of Accounting 3 (4): 112.

Raharjo, Dul Muid Daniarto. 2013. “Analisis Pengaruh Faktor-Faktor Fundamental Rasio Keuangan Terhadap Perubahan Harga Saham." Diponegoro Journal Of Accounting 2 (2): 1-11.

Raharjo, Sugeng. 2020. "Pengaruh Inflasi, Nilai Kurs Rupiah, Dan Tingkat Suku Bunga Terhadap Harga Saham Di Bursa Efek Indonesia."

https://media.neliti.com/media/publications/ 161972-ID-None.pdf/diunduh 25 Maret 2020. Surakarta.

Riyadi, Selamet. 2014. "Analisis Pengaruh Kinerja Keuangan, BI Rate Dan Earning Per Share Terhadap Harga Saham Bank BUMN Di Bursa Efek Indonesia (Periode 2008-2013)." Jurnal Ekonomi, Manajemen Dan Akuntansi 17 (2): 85-96.

Sartono, Agus. 2010. Manajemen Keuangan Teori Dan Aplikasi. Edited by Ali Akbar Yulianto. Edisi 11. Yogyakarta: BPFE Yogyakarta.

Sawir, Agnes. 2005. Analisis Kinerja Keuangan Dan Perencanaan Keuangan Perusahaan. Jakarta: Gramedia Pustaka Utama Persada.

Sha, Thio Lie. 2015. "Pengaruh Kebijakan Dividen, Likuiditas, Net Profit Margin, Return on Equity, Dan Price To Book Value Terhadap Harga Saham Pada Perusahaan Manufaktur Yang Terdaftar Di Bursa Efek Indonesia 2010 - 2013." Jurnal Akuntansi 19 (2): 276-94. https://doi.org/10.24912/ja.v19i2.99.

Subiyantoro, Edi, and Fransisca Andreani. 2003. "Analisis Faktor-Faktor Yang Mempengaruhi Harga Saham (Kasus Perusahaan Jasa Perhotelan Yang Terdaftar Di Pasar Modal Indonesia)." Jurnal Manajemen Dan Wirausaha 5 (2): 171-80. https://doi.org/10.9744/jmk.5.2.pp.171-180.

Sugiyono. 2007. Metode Penelitian Bisnis (Pendekatan Kuantitatif, Kualitatif Dan $R \& D) . \quad 2$ 2nded. Bandung: Alfabeta. website:www.cvalfabeta.com.
Suliyanto. 2011. Ekonometrika Terapan Teori \& Apalikasi Dengan SPSS. Edited by Fl. Sigit Suyantoro. Ed.I. Yogyakarta: CV.ANDI OFSET.

Sunardi, Nardi, Laila Nurmillah, and Rabiul Ula. 2017. "Pengaruh Bi Rate, Inflasi Dan Kurs Terhadap Indeks Harga Saham Gabungan (IHSG)." Jurnal Sekuritas 1 (2): 27-41.

Sunariyah. 2003. Pengantar Pengetahuan Pasar Modal. Ketiga. Yogyakarta: UPP AMP YKPN.

Suselo, Dedi, Atim Djazuli, and Nur Khusniyah Indrawati. 2015. "Pengaruh Variabel Fundamental Dan Makro Ekonomi Terhadap Harga Saham (Studi Pada Perusahaan Yang Masuk Dalam Indeks LQ45)." Jurnal Aplikasi Manajemen (JAM) 13 (1): 104-16. http://jurnaljam.ub.ac.id/index.php/jam/articl e/view/734\%0Ahttp://www.jurnaljam.ub.ac.i d/index.php/jam/article/view/734.

Swaputra, Ida Bagus, Purba I Made Astakoni, Mela Putu Ratini, and Sri Tjok Istri Harwathy. 2018. "Ukuran Perusahaan,Pertumbuhan, Dan Struktur Modal Sebagai Determinan Profitabilitas Perusahaan." Jurnal Riset Akuntansi Juara 8 (2): 24-36.

Tandelilin, Eduardus. 2001. Analisis Investasi Dan Manajemen Portofolio. I. Yogyakarta: Badan Penerbit Fakultas Ekonomi (BPFE).

Tandelilin, Eduardus. 2010. Portofolio Dan Investasi. Edisi Pert. Yogyakarta: Kanisius.

Thobarry, Achmad Ath. 2009. "Analisis Pengaruh Nilai Tukar, Suku Bunga, Laju Inflasi Dan Pertumbuhan GDP Terhadap Indeks Harga Saham Sektor Properti (Kajian Empiris Pada Bursa Efek Indonesia Periode Pengamatan Tahun 2000-2008." Universitas Diponogoro Semarang. http://eprints.undip.ac.id/19029/.

Wardani, Dewi Kusuma, and Devita Fajar Tri Andarini. 2016. "Pengaruh Kondisi Fundamental, Inflasi Dan Suku Bunga Sertifikat Bank Indonesia Terhadap Harga Saham (Study Kasus Pada Perusahaan Real Estate Dan Property Yang Terdaftar Di Bursa Efek Indonesia Tahun 2010-2013)." Jurnal Akuntansi 4 (2): 77-90. https://doi.org/10.24964/ja.v4i2.233.

Wardita, I Wayan, and I Made Purba Astakoni. 2018. "Profitabilitas, Pertumbuhan Perusahaan Dan Ukuran Perusahaan Sebagai Determinan Struktur Modal." KRISNA: 
Kumpulan Riset Akuntansi 9 (2): 20. https://doi.org/10.22225/kr.9.2.468.20-32.

Weston, J.F, and T.E Copeland. 2008. Dasar Dasar Manajemen Keuangan. 2nded. Jakarta: Erlangga.

Wibowo, Satrio. 2012. "Pengaruh Nilai Tukar,
Suku Bunga,Sertifikat Bank Indonesia Dan Indeks Saham Gabungan Dow Jones Terhadap Indeks Harga Saham Gabungan Indonesia." Jurnal Bisnis Dan Akuntansi 14 (2): 117-30. 